\title{
Nutrient cycling and field-based partial nutrient balances in two mountain oases of Oman
}

\author{
Andreas Buerkert ${ }^{\mathrm{a}, *}$, Maher Nagieb ${ }^{\mathrm{a}}$, Stefan Siebert ${ }^{\mathrm{a}}$, \\ Iqrar Khan ${ }^{\mathrm{b}}$, Ahmed Al-Maskri ${ }^{\mathrm{b}}$

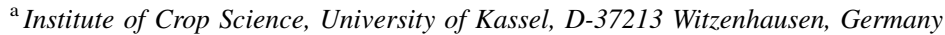 \\ ${ }^{\mathrm{b}}$ College of Agriculture and Marine Sciences, Sultan Qaboos University, Al Khod, Oman
}

Received 6 August 2004; received in revised form 13 December 2004; accepted 23 December 2004

\begin{abstract}
Little is known about nutrient fluxes as a criterion to assess the sustainability of traditional irrigation agriculture in eastern Arabia. In this study GIS-based field research on terraced cropland and groves of date palm (Phoenix dactylifera L.) was conducted over 2 years in two mountain oases of northern Oman to determine their role as hypothesized sinks for nitrogen $(\mathrm{N})$, phosphorus (P) and potassium (K). At Balad Seet $55 \%$ of the 385 fields received annual inputs of $100-500 \mathrm{~kg} \mathrm{~N} \mathrm{ha}^{-1}$ and $26 \%$ received $500-1400 \mathrm{~kg} \mathrm{~N} \mathrm{ha}^{-1}$. No $\mathrm{N}$ was applied to $19 \%$ of the fields which were under fallow. Phosphorus was applied annually at $1-90 \mathrm{~kg} \mathrm{ha}^{-1}$ on $46 \%$ of the fields, whereas $27 \%$ received $90-210 \mathrm{~kg} \mathrm{ha}^{-1}$. No K was applied to $27 \%$ of the fields, $32 \%$ received $1-300 \mathrm{~kg} \mathrm{~K} \mathrm{ha}^{-1}$, and the remaining fields received up to $1400 \mathrm{~kg} \mathrm{ha}^{-1}$. At Maqta N-inputs were $61-277 \mathrm{~kg} \mathrm{ha}^{-1}$ in palm groves and $112-225 \mathrm{~kg} \mathrm{ha}^{-1}$ in wheat (Triticum spp.) fields, respective $\mathrm{P}$ inputs were $9-40$ and $14-29 \mathrm{~kg} \mathrm{ha}^{-1}$, and $\mathrm{K}$ inputs were 98-421 and 113-227 kg ha ${ }^{-1}$. For cropland, partial oasis balances (comprising inputs of manure, mineral fertilizers, $\mathrm{N}_{2}$-fixation and irrigation water, and outputs of harvested products) were similar for both oases, with per hectare surpluses of $131 \mathrm{~kg} \mathrm{~N}, 37 \mathrm{~kg} \mathrm{P}$, and $84 \mathrm{~kg} \mathrm{~K}$ at Balad Seet and of $136 \mathrm{~kg} \mathrm{~N}, 16 \mathrm{~kg} \mathrm{P}$ and $66 \mathrm{~kg} \mathrm{~K}$ at Maqta. This was despite the fact that $\mathrm{N}_{2}$-fixation by alfalfa (Medicago sativa L.), estimated at up to $480 \mathrm{~kg} \mathrm{ha}^{-1} \mathrm{yr}^{-1}$ with an average total dry matter of $22 \mathrm{t} \mathrm{ha}^{-1}$, contributed to the cropland N-balance only at the former site. Respective palm grove surpluses, in contrast were with $303 \mathrm{~kg} \mathrm{~N}$, $38 \mathrm{~kg} \mathrm{P}$, and $173 \mathrm{~kg} \mathrm{~K} \mathrm{ha}^{-1}$ much higher at Balad Seet than with $84 \mathrm{~kg} \mathrm{~N}, 14 \mathrm{~kg} \mathrm{P}$, and $91 \mathrm{~kg} \mathrm{~K} h a^{-1}$ at Maqta. The data show that both oases presently are large sinks for nutrients. Potential gaseous and leaching losses could at least partly be controlled by a decrease in nutrient input intensity and careful incorporation of manure.
\end{abstract}

(C) 2004 Elsevier B.V. All rights reserved.

Keywords: Animal manure; Irrigation agriculture; $\mathrm{N}_{2}$-fixation; Nutrient fluxes; Sustainability

\section{Introduction}

* Corresponding author. Tel.: +49 554298 1228; fax: +495542981230.

E-mail address: buerkert@uni-kassel.de (A. Buerkert).
In recent years the determination of carbon $(\mathrm{C})$ and nutrient fluxes in agro-ecosystems has received increasing attention by agricultural scientists world- 
wide as it seems to offer a way of objectively assessing a system's sustainability and the potential side effects of management on the environment at different scales. Much of the initial work was triggered by Dutch scientists working on low-input cropping systems in Africa (Baijukya and de Steenhuijsen Piters, 1998; Wijnhoud et al., 2003). Driven by concerns about the impact of human management on soil fertility leading to a perceived large scale soil depletion and degradation or farmers' indigenous productivity management strategies (Harris, 1998), bio-physical modeling tools such as NUTMON were used to assess data on both the input and output side of nutrient balances at the field, district, and country level (Smaling et al., 1993, 1996; Smaling and Fresco, 1993; Stoorvogel and Smaling, 1994; De Jaeger et al., 1998a,b; Van den Bosch et al., 1998a,b).

Simultaneously, European and American scientists, driven by concerns about greenhouse gas emissions in temperate agro-ecosystems and in intensively managed Asian rice, developed new methods to reliably estimate nitrogen $(\mathrm{N})$ and $\mathrm{C}$ losses to the atmosphere and to monitor the effects of management changes on nutrient fluxes (Ko and Kang, 2000; Wang and Adachi, 2000; Wassmann et al., 2000; Xu et al., 2000; Butterbach-Bahl et al., 2001). Depending on the aim and scale of the research, either full or partial balances were used. Full balances comprised measurements or estimates of inputs such as mineral fertilizers, manure, $\mathrm{N}_{2^{-}}$ fixation by leguminous crops and free living microorganisms, nutrient acquisition from deeper soil layers, human faeces, irrigation water, and dry and wet atmospheric deposition. Outputs included removed yields, erosion, atmospheric emissions, and leaching losses. Partial balances, in contrast, assumed that variables such as atmospheric deposition, gaseous emissions, or leaching losses are either too difficult to measure or to model at the required resolution or are negligible in size compared to the other variables.

Whereas most published work focuses on rainfed or irrigated agriculture with relatively simple cropping systems, little information is available on nutrient fluxes in more complex, small scale crop rotations such as practiced in intensively irrigated desert oasis systems of eastern Arabia. To fill this gap of knowledge, this study reports data from two ancient oases in the mountains of northern Oman, where the large $\mathrm{C}$ turnover on intensively manured soils with low $\mathrm{C}: \mathrm{N}$ ratios has been the subject of earlier work (Wichern et al., 2004a,b). Our underlying hypothesis was that one of the decisive causes of the productivity of the oasis agriculture under study was their role as sinks for nutrients, leading to large positive partial balances of $\mathrm{N}$, phosphorus $(\mathrm{P})$, and potassium $(\mathrm{K})$.

\section{Materials and methods}

\subsection{Description of the agroecosystems}

The study area comprised two contrasting springfed oases in the al-Hajar mountains of Oman. Despite being at the upper end of large watersheds, both have no regular runoff, but irrigation combined with occasional torrential rainfalls in winter can lead to rapid leaching and flash floods that rush through the barren wadis. The agro-ecological setting and physical structure of the oases were as follows.

Balad Seet $\left(23.19^{\circ} \mathrm{N}, 57.39^{\circ} \mathrm{E}\right.$; $950-1020 \mathrm{~m}$ a.s.l.; $0-240 \mathrm{~mm}$ of total average annual precipitation) is situated in a small valley at the upper end of the Wadi Bani Awf watershed in the Jabal Akhdar range. It is a typical 'core oasis' with a central settlement on a rocky outcrop at the upper end of six surrounding terrace systems (Fig. 1; Nagieb et al., 2004). The 385 agricultural fields are situated on terraced Irragric Anthrosols (FAO, 2001) of 0.4-1.3 m profile depth with 9-14\% clay and an organic $\mathrm{C}$ concentration of $3.7 \%$ at $0-0.15 \mathrm{~m}$ and of $3 \%$ at $0.15-0.45 \mathrm{~m}$ (Luedeling et al., 2005). These fields totaled 4.6 ha to which 2690 date palms (Phoenix dactylifera L.) comprising 16 varieties interplanted with some lime (Citrus aurantiifolia [Christm. et Panz.] Swingle) and a few banana (Musa spp.) plants have to be added, which together cover an additional 8.8 ha of terraced land. About 1.9 ha of the palm groves were sown to understory grasses, which were cut three times per year and fed to goat and sheep as a feed supplement. Of the total number of date palms 58\% were bearing fruit during the 24 months of study from October 2000 to October 2002. The main cultivated plants were perennial alfalfa (Medicago sativa L.) and annual crops such as traditional wheat landraces (Triticum aestivum L. and Triticum durum; Al-Maskri et al., 


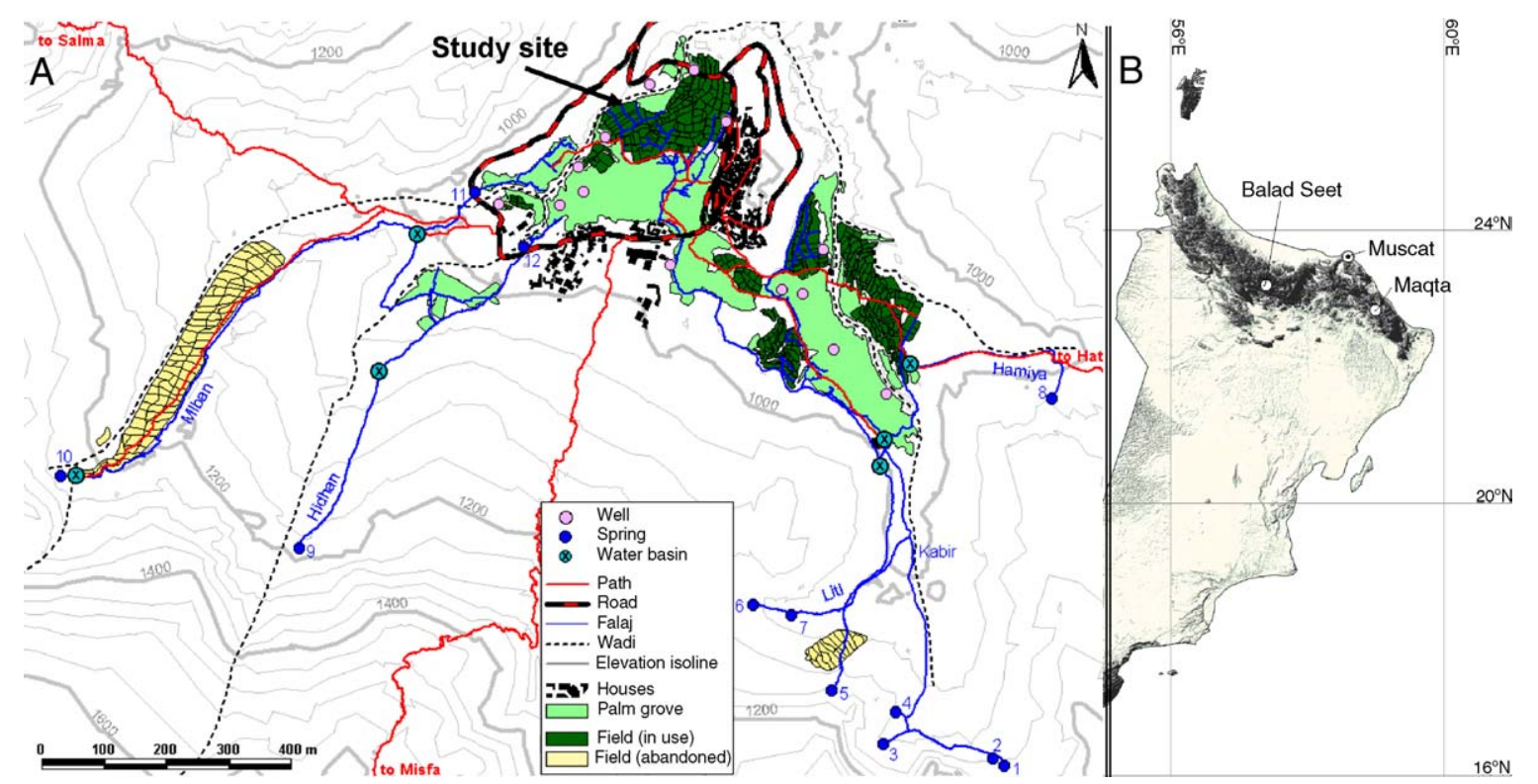

Fig. 1. GIS-based map with the main features of the 'core oasis' of Balad Seet, Oman (left) and position of the two mountain oases under study (right). The arrow indicates the field where the ${ }^{15} \mathrm{~N}$ experiment was conducted to quantify $\mathrm{N}_{2}$-fixation of alfalfa.

2003), sorghum (Sorghum bicolor Moench s. 1.), barley (Hordeum vulgare L. s. 1.), oat (Avena sativa L.), garlic (Allium sativum L.) and onion (Allium cepa L.). These were planted in complex summer-winter crop rotation systems (Fig. 2). The village's 650 inhabitants, exceeding several times the assumed traditional agricultural carrying capacity of the oasis (Nagieb et al., 2004), were distributed in 80 households. Recent studies (Nagieb et al., 2004) indicated that the settlement history of this oasis may date back as far as to the second millenium BC. This likely reflects the ideal ecological conditions provided by an abundant and relatively stable water supply from 12 springs originating at the foot of a $1000 \mathrm{~m}$ high calcareous cliff (Luedeling et al., 2005). Depending on rainfall conditions, the total flow of the springs varied between 20 and $30 \mathrm{~m}^{3} \mathrm{~h}^{-1}$ during the study period. An elaborate spring irrigation system (sing. falaj, pl. aflaj in Arabic) conveys the water to the cropland and the palm groves.

Maqta, at the upper end of the widely open Wadi Khabbah in the Jabal Bani Jabir mountains, in contrast, is a typical 'scattered oasis' with a central village area $\left(59.00^{\circ} \mathrm{E}, 22.83^{\circ} \mathrm{N} ; 1050 \mathrm{~m}\right.$ a.s.l.) of 73 houses and 12 widely dispersed temporary settlements in a vast rocky grazing area (Fig. 3; Siebert et al.,
2005). In 2001 the total agro-pastoral population of this territorial unit numbered about 200. The 5.2 ha terraced agricultural area of interest for this study were divided into 130 fields on 17 terrace systems, in which terrace size ranged from 32 to $22,200 \mathrm{~m}^{2}$ (Fig. 4). Palm groves totaled 3.6 ha with 2128 trees of which 937 were productive. On 1.2 ha of the palm groves fodder grasses were grown, cut as in Balad Seet three times a year, and fed to goat and sheep. Additionally there were 0.4 ha of wheat of the Walidi landrace (AlMaskri et al., 2003) growing on 10 of the 17 terrace systems, plus 0.4 ha of fallow, and 0.8 ha of abandoned land. The total flow of the 22 springs was between 4.8 and $9.0 \mathrm{~m}^{3} \mathrm{~h}^{-1}$ during the 12-month measurement period of this study (February 2001March 2002). In the hot summer water was applied to the palm groves only.

At both oases all agronomically relevant measurements were based on the initial establishment of a three-dimensional digital map established within a Geographical Information System (GIS) in April 2000. Low altitude aerial photography (Buerkert et al., 1996) and ground-truth data collected with a differential Global Positioning System (GPS; Trimble Pathfinder, Sunnyvale, CA, USA) at decimeter precision were used to record important features 


\section{Month of the year}

Oct. Nov. Dec. Jan. Feb. Mar. Apr. May Jun. Jul. Aug. Sep.
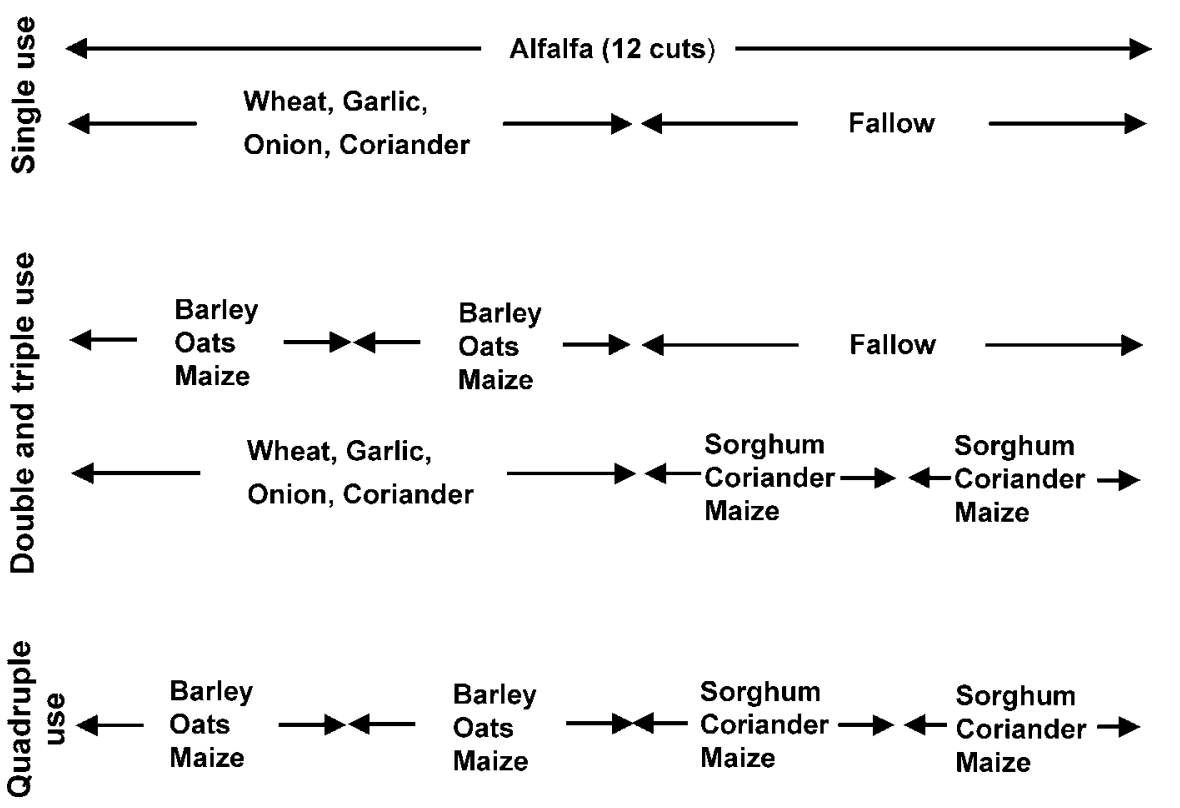

Fig. 2. Cropping sequences on terraced fields at Balad Seet, Oman.

governing the agricultural system of the oasis such as water basins, main irrigation channels, the contours of the terraces, roads, and foot paths. Also the variety and age class (young versus fruit bearing) of each palm tree were noted. The precise size of individual fields and their cropping sequence as well as the data about the heavily fertilized date palms was needed for the establishment of partial nutrient balances.

\subsection{Outputs (nutrient exports)}

For crops and dates the calculation of nutrient exports was based on the amounts of N, P and $\mathrm{K}$ that were removed with the harvested dry matter from an individual field during the respective measurement periods. Nutrients removed with harvested under-story fodder grasses were estimated based on two representative samples from Balad Seet and one sample from Maqta. At neither site were nutrient losses by leaching, denitrification and volatilization, nor $\mathrm{N}$ gains from atmospheric deposition and non-symbiotic $\mathrm{N}_{2-}$ fixation accounted for.
Balad Seet. For yield measurements, four representative reference fields were selected for each of the eight crops grown in the different rotation systems of the oasis. These reference fields were classified into four yield classes (low, medium, high, very high) and harvested. Depending on the crop grown total biomass or straw and grain yields were determined after sun drying to weight constancy on all 32 fields. Subsequently, the yields of the remaining fields were estimated based on those of the reference fields (yield classes). To calculate above-ground nutrient uptake, the estimated yield of each individual plot was multiplied by the respective concentrations of total nitrogen $(\mathrm{N})$, phosphorus $(\mathrm{P})$ and potassium $(\mathrm{K})$ in the reference plot of the corresponding yield class. Total $\mathrm{N}$ was determined with a N-Analyzer (FP-328 LECO, $\mathrm{Mi}$, USA) with standards being included every 15 samples, P colorimetrically (Hitachi U-2000 spectrophotometer, Japan) according to the vanado-molybdate method (Gericke and Kurmies, 1952), and K by flame photometry (Instrument Laboratory 543, CA, USA). 


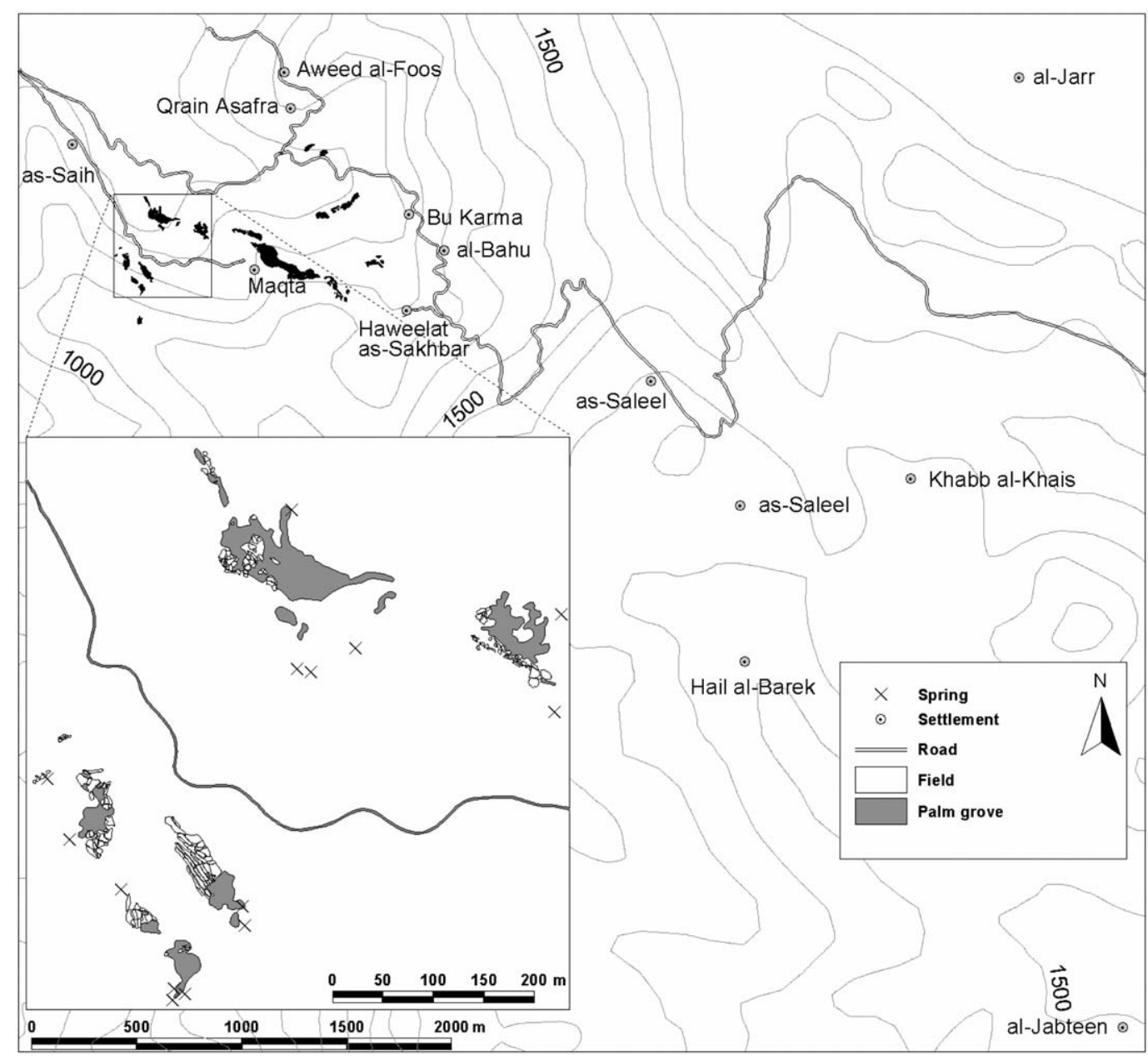

Fig. 3. GIS-based map of the Maqta territory in Oman with the terrace systems, the central housing area, the dispersed settlements, the natural grazing basin, major archaeological sites and altitude lines (Siebert et al., 2005).

To estimate the date yields for the 1685 individual fertile trees of Balad Seet, a single representative palm grove with 171 fruit bearing palms was used as a reference. First, the fresh weight of the dates on each tree of the grove was estimated with the help of their owners based on the number and size of the date bundles. Subsequently, the fresh yields of all other trees in the oasis were estimated according to the average yield determined for each variety grown in the reference grove. Samples of 14 date varieties were freeze-dried and their $\mathrm{N}, \mathrm{P}$ and $\mathrm{K}$ concentration determined as above and total nutrient uptake in the dry matter calculated.

Maqta. In each of the small 10 terrace systems cultivated with wheat, one single field was chosen at random for measurement of grain and straw yield and for determination of $\mathrm{N}, \mathrm{P}$ and $\mathrm{K}$ concentrations.

The amounts of $\mathrm{N}, \mathrm{P}$ and $\mathrm{K}$ accumulated annually in growing palm leaves and trunk parts were estimated based on data from the literature (IFA, 2004). These assume that adult trees with about $70 \mathrm{~kg}$ edible dates $\mathrm{yr}^{-1}$ produce a vegetative biomass of $50 \mathrm{~kg}$ dry matter with concentrations of $8.6 \mathrm{~g} \mathrm{~N} \mathrm{~kg}^{-1}, 1 \mathrm{~g} \mathrm{P} \mathrm{kg}^{-1}$ and $30 \mathrm{~g} \mathrm{~K} \mathrm{~kg}^{-1}$. As $\mathrm{P}$ and $\mathrm{K}$ accumulated in the vegetative biomass is over time effectively recycled through ash from the eventually burned tissue in both oasis settings, only $\mathrm{N}$ losses are relevant for the calculation of partial nutrient balances. For Balad Seet such annual $\mathrm{N}$ losses were estimated at about $215 \mathrm{~g} \mathrm{~N}$ 


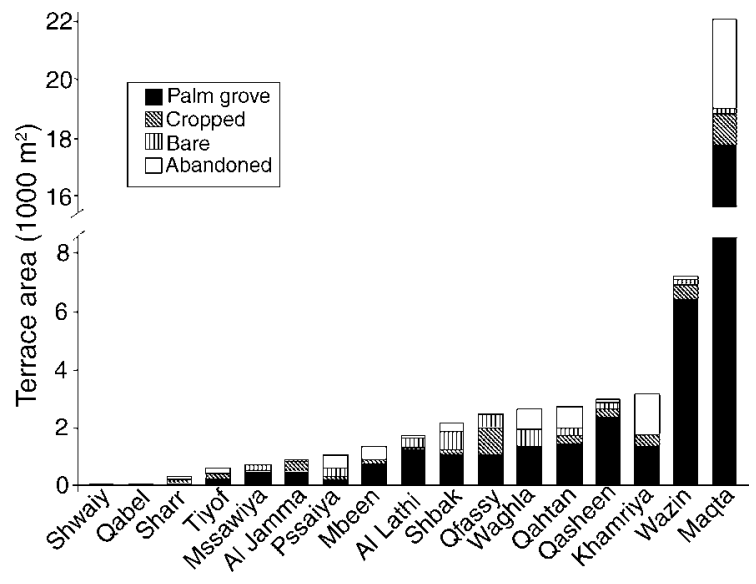

Fig. 4. Size and land use of the 17 terrace systems at the 'scattered' oasis of Maqta, Oman.

per fruit bearing tree with $35 \mathrm{~kg}$ of dates and at $54 \mathrm{~g}$ per young tree. At Maqta annual $\mathrm{N}$ losses in the burned palm tree tissue were adjusted for the lower date yields of this site and were thereby estimated at $60 \mathrm{~g} \mathrm{~N}$ per fruit bearing tree with $10 \mathrm{~kg}$ of dates and at $15 \mathrm{~g}$ per young tree.

\subsection{Inputs}

Balad Seet. Nutrient inputs to crops consisted of a widely varying mixture of air-dried manure compost comprised of about one-half from goat and sheep manure and about one-half from cattle manure complemented by applications of the synthetic fertilizers NPK (15-15-15) and urea (46-0-0). Manure was typically hand-applied in units of full jute bags for which an average content weight was determined based on 10 filled sample bags. Manure composition was determined twice during the measurement period by taking 12 and 8 samples, respectively, from different bags and analyzing them individually for $\mathrm{N}$, P, and $\mathrm{K}$ concentrations as above. For subsequent calculations of field-based nutrient budgets median values of the twenty measurements were used.

Nutrients applied through synthetic fertilizers to each crop were measured by a detailed survey of each farm household, field visits and a verification survey of the total number of urea and NPK fertilizer bags purchased annually by the villagers.

At Balad Seet biological $\mathrm{N}_{2}$-fixation in alfalfa was estimated from a 18 -month long factorial ${ }^{15} \mathrm{~N}$ study $\left({ }^{15} \mathrm{~N}\right.$ was applied twice at $15.1 \mathrm{~g}\left(\mathrm{NH}_{4}\right)_{2} \mathrm{SO}_{4}$ enriched with $10 \%{ }^{15} \mathrm{~N}$ ) with wheat as a test crop. First data indicated $\mathrm{N}_{2}$-fixation rates (dNfa) of $69-85 \%$ at an alfalfa shoot $\mathrm{N}$ concentration of $29 \mathrm{~g} \mathrm{~kg}^{-1}$ (Nagieb, 2004). Based on these results an average $\mathrm{N}_{2}$-fixation rate (Ndfa) of $75 \%$ was used to estimate the contribution of symbiotically fixed $\mathrm{N}$ in the harvested shoot dry matter. It was further estimated that the amount of symbiotically fixed $\mathrm{N}$ stored in the roots and released or recycled in the rhizosphere amounted to about one-third of the above ground N. From this it was assumed that total $\mathrm{N}_{2}$-fixation of the crop corresponded to the entire amount of $\mathrm{N}$ removed with harvested alfalfa shoots. In the balance calculations $\mathrm{N}$ uptake with the harvested alfalfa was accounted for once as export and once as input (fixation). The effect of $\mathrm{N}_{2}$-fixation on partial balances appeared thus indirectly in the manure component into which all alfalfa fed to animals was finally converted.

Maqta. The only source of nutrient inputs was goat and sheep manure, as neither synthetic fertilizers nor $\mathrm{N}_{2}$-fixing alfalfa were used.

At both sites also the amounts of N, P and $\mathrm{K}$ in the night soil produced from human faeces and applied to palm trees in irregular intervals were considered. As recording of human faeces was a culturally sensitive issue, no actual data could be taken in either oasis and data from the literature for the total daily nutrient excretion of adults in Thailand had to be used instead (7.8 g N, $1.7 \mathrm{~g}$ P and $2.3 \mathrm{~g} \mathrm{~K}$ per person; Schouw et al., 2002). At Balad Seet, of the 632 inhabitants living in the oasis 367 were adults with an age of $\geq 15$ and counted with a relative weight factor of 1,168 were adolescents and counted with a weight factor of 0.75 , and 97 were children $\leq 5$ years old and counted with a weight factor of 0.33 . At Maqta, in contrast, only 25 of the 200 inhabitants living in the vast agro-pastoral territory took shifts watering the terraces and may thus have actively contributed their faeces to the nutrient inputs. Of those 14 were adults and 11 adolescents.

The last recorded input variable was the nutrient contribution through irrigation water. Its $\mathrm{N}, \mathrm{P}$, and $\mathrm{K}$ concentration was determined several times for the major falaj-systems at Balad Seet and once for the important springs at Maqta. Data were weighted for the respective spring flows and multiplied by the total amount of water applied during the respective 12- and 24-month measurement periods. 


\subsection{Analysis of nutrient fluxes}

Balad Seet. All nutrient outputs (in all harvested products) and inputs (in manure, synthetic fertilizers, irrigation water and human faeces, as well as the amount of $\mathrm{N}_{2}$-fixed by alfalfa) measured for crops and date palms over the 24-month study period were recorded and subsequent partial balance sheets computed at the level of individual fields and for the oasis as a whole.

Maqta. Given its much more scattered structure, the basis for recorded parameters and computed partial balances were the 17 individual terrace systems and the oasis as a whole. As no synthetic fertilizers or alfalfa were used in this oasis, all input calculations were based on the amounts of manure applied annually to date palms and wheat fields.

For crops, field-based (Balad Seet) or terrace-based (Maqta) average annual $\mathrm{N}, \mathrm{P}$, and $\mathrm{K}$ inputs were plotted as absolute quantities (frequency distributions) for several input classes whose size differed for the nutrients. To examine whether these input distributions depended on field size, the displayed plots at
Balad Seet differentiated between fields of $<72,72$ 138 , and $>138 \mathrm{~m}^{2}$. These classes were chosen based on the frequency distribution of all field sizes. Subsequently field- or terrace-based partial nutrient balances were computed. For date palms input and output fluxes were summarized at the oasis level (Balad Seet) or displayed for each terrace separately (Maqta).

At both sites partial oasis balances were set up to show aggregated inputs and outputs, according to the type of land use (cropland versus palm groves) on a per hectare basis and for the oasis as a whole.

\section{Results}

\subsection{Annual crop yields, nutrient concentrations, and nutrient exports}

At Balad Seet cereal yields averaged $2980 \mathrm{~kg} \mathrm{ha}^{-1}$ for wheat grain. Respective total dry matter (TDM) yields of fodder barley and fodder oats were 5420 and $5370 \mathrm{~kg} \mathrm{ha}^{-1}$, and TDM of maize was $5490 \mathrm{~kg} \mathrm{ha}^{-1}$.

Table 1

Air-dried shoot yields $\left(\mathrm{kg} \mathrm{ha}^{-1}\right)$ for four yield classes of the major crops grown at the core oasis of Balad Seet (Oman) in the 2000/2001 and the 2001/2002 cropping seasons

\begin{tabular}{|c|c|c|c|c|c|c|c|c|}
\hline \multirow[t]{2}{*}{ Crop } & \multicolumn{4}{|l|}{ Straw } & \multicolumn{4}{|l|}{ Grain } \\
\hline & Low & Medium & High & Very high & Low & Medium & High & Very high \\
\hline \multicolumn{9}{|l|}{$2000 / 2001$} \\
\hline Wheat & 11070 & 11250 & 11880 & 11970 & 2610 & 2700 & 3060 & 3150 \\
\hline Barley & 5490 & 6300 & 6570 & 7020 & a & a & a & a \\
\hline Sorghum & 11440 & 12760 & 13200 & 14960 & 2250 & 2250 & 2790 & 3240 \\
\hline Maize & 5670 & 6480 & 6660 & 6940 & a & a & a & a \\
\hline Oat & 5730 & 6090 & 6730 & 6910 & a & a & a & a \\
\hline Alfalfa ${ }^{\mathrm{b}}$ & 1820 & 1910 & 2360 & 2450 & a & a & a & $\mathrm{a}$ \\
\hline Garlic & 1890 & 2060 & 2150 & 3270 & $5180^{c}$ & $5340^{c}$ & $5770^{\mathrm{c}}$ & $9940^{c}$ \\
\hline Coriander & 3400 & 3500 & 4000 & 4400 & a & a & a & $\mathrm{a}$ \\
\hline \multicolumn{9}{|l|}{$2001 / 2002$} \\
\hline Wheat & 6300 & 8100 & 10800 & 11970 & 2020 & 2880 & 3600 & 3780 \\
\hline Barley & 3600 & 4050 & 4500 & 5850 & a & a & a & $\mathrm{a}$ \\
\hline Sorghum & 11700 & 12600 & 13500 & 15300 & 2160 & 2250 & 2790 & 3060 \\
\hline Maize & 2880 & 4500 & 4950 & 5850 & a & $\mathrm{a}$ & a & a \\
\hline Oat & 3640 & 3820 & 4550 & 5460 & a & $\mathrm{a}$ & a & a \\
\hline Alfalfa ${ }^{\mathrm{b}}$ & 910 & 1460 & 1640 & 2460 & a & a & a & a \\
\hline Garlic & 1720 & 2150 & 2580 & 3440 & $4680^{c}$ & $5460^{\mathrm{c}}$ & $7020^{c}$ & $10140^{\mathrm{c}}$ \\
\hline Coriander & 2250 & 2520 & 2880 & 3420 & a & a & & a \\
\hline
\end{tabular}

\footnotetext{
a Only vegetative parts were harvested and except for animals used as animal fodder.

b Yields refer to a single cut, there typically were 12 cuts per year.

${ }^{c}$ Dry bulbs.
} 
Table 2

Air-dried straw and grain yields $\left(\mathrm{kg} \mathrm{ha}^{-1}\right)$ of the Walidi wheat landrace and concentrations $\left(\mathrm{g} \mathrm{kg}^{-1}\right)$ of nitrogen $(\mathrm{N})$, phosphorus $(\mathrm{P})$ and potassium (K) for different yield classes (terrace level) at the scattered oasis of Maqta (Oman) in the 2001/2002 season

\begin{tabular}{|c|c|c|c|c|c|c|c|c|}
\hline \multirow[t]{2}{*}{ Class } & \multicolumn{4}{|c|}{ Wheat straw } & \multicolumn{4}{|c|}{ Wheat grain } \\
\hline & Low & Medium & High & Very high & Low & Medium & High & Very high \\
\hline Dry matter & 6580 & 8460 & 8460 & 9400 & 1800 & 2070 & 2250 & 2700 \\
\hline $\mathrm{N}$ & 2.3 & 3.1 & 3.3 & 3.8 & 16.2 & 16.5 & 18.3 & 15.4 \\
\hline $\mathrm{P}$ & 0.4 & 0.4 & 0.3 & 0.5 & 2.8 & 2.5 & 2.6 & 2.8 \\
\hline K & 18.9 & 11.9 & 13.1 & 19.5 & 3.4 & 3.1 & 3.0 & 3.3 \\
\hline
\end{tabular}

There was an overall crop yield difference between years, with the 2000/2001 season having higher yields than 2001/2002 (Table 1). With 12 cuts per year, average annual alfalfa TDM amounted to $22,520 \mathrm{~kg}$ $\mathrm{ha}^{-1}$. At Maqta wheat yields were $2210 \mathrm{~kg} \mathrm{ha}^{-1}$, much lower than at Balad Seet. The same was true for the nutrient concentrations in wheat (Tables 2 and 3).

\subsection{Nutrient inputs and partial balances}

Balad Seet. During the 2-year measurement period, $55 \%$ of the 385 fields received total annual $\mathrm{N}$ inputs of $100-500 \mathrm{~kg} \mathrm{~N}^{-1}, 25 \%$ received $500-1400 \mathrm{~kg} \mathrm{~N}$ $\mathrm{ha}^{-1}$, and $11 \%$ did not receive N. Annual $\mathrm{P}$ applications of up to $90 \mathrm{~kg} \mathrm{Pha}^{-1}$ were applied on $46 \%$ of the fields, whereas $27 \%$ received 90 $210 \mathrm{~kg} \mathrm{P} \mathrm{ha}^{-1}$, and the same percentage received no P. Similarly to P no K was applied on $27 \%$ of the fields, whereas $32 \%$ received $1-300 \mathrm{~kg} \mathrm{Kha}^{-1}$, and the remaining fields received up to $1400 \mathrm{~kg} \mathrm{~K} \mathrm{ha}^{-1}$ (Fig. 5). The distribution of all three nutrients tended to be slightly skewed at the upper end meaning that large fields tended to receive higher input intensities than small ones. The majority of the input distribution curve, however, appeared to be unaffected by field size (Fig. 5). Bi-annual partial balances of $\mathrm{N}$ were positive on $82 \%$, of $\mathrm{P}$ on $79 \%$, and of $\mathrm{K}$ on $63 \%$ of the fields (Fig. 6). Nutrient concentrations in irrigation water were $0.57 \mathrm{mg} \mathrm{N}^{-1}, 0.30 \mathrm{mg} \mathrm{P}^{-1}$, and $1.0 \mathrm{mg} \mathrm{K}^{-1}$.

Maqta. Palm groves clearly dominated the cultivated land on all but the Qfassy terrace system and large proportions of their land was temporarily uncultivated (bare) and abandoned (Fig. 4). Manure application led to $\mathrm{N}$-inputs from 61 to $277 \mathrm{~kg} \mathrm{~N}^{-1}$ in palm groves and from 112 to $225 \mathrm{~kg} \mathrm{~N} \mathrm{ha}^{-1}$ in wheat fields, to $\mathrm{P}$ inputs from 9 to $40 \mathrm{~kg} \mathrm{Pha}^{-1}$ in palms and 14 to $29 \mathrm{~kg} \mathrm{P} \mathrm{ha}^{-1}$ in wheat, and to $\mathrm{K}$ inputs from 98 to $421 \mathrm{~kg} \mathrm{~K} \mathrm{ha}^{-1}$ in palms and 113 to $227 \mathrm{~kg} \mathrm{~K} \mathrm{ha}^{-1}$ in wheat (Fig. 7). With the exception of the tiny and poorly fertilized Shwaiy system, which did not contain wheat fields, differences in overall input intensity between terraces were with correlation

Table 3

Concentrations of nitrogen $(\mathrm{N})$, phosphorus $(\mathrm{P})$ and potassium $(\mathrm{K})$ for four yield classes of the major crops grown at the core oasis of Balad Seet (Oman) in the 2000/2001 season

\begin{tabular}{|c|c|c|c|c|c|c|c|c|c|c|c|c|c|c|c|c|c|c|c|c|c|c|c|c|}
\hline \multirow[t]{3}{*}{ Class } & \multicolumn{12}{|c|}{ Straw } & \multicolumn{12}{|l|}{ Grain } \\
\hline & \multicolumn{3}{|l|}{ Low } & \multicolumn{3}{|c|}{ Medium } & \multicolumn{3}{|c|}{ High } & \multicolumn{3}{|c|}{ Very high } & \multicolumn{3}{|l|}{ Low } & \multicolumn{3}{|c|}{ Medium } & \multicolumn{3}{|l|}{ High } & \multicolumn{3}{|c|}{ Very high } \\
\hline & $\mathrm{N}$ & $\mathrm{P}$ & $\mathrm{K}$ & $\mathrm{N}$ & $\mathrm{P}$ & $\mathrm{K}$ & $\mathrm{N}$ & $\mathrm{P}$ & $\mathrm{K}$ & $\mathrm{N}$ & $\mathrm{P}$ & $\mathrm{K}$ & $\mathrm{N}$ & $\mathrm{P}$ & $\mathrm{K}$ & $\mathrm{N}$ & $\mathrm{P}$ & $\mathrm{K}$ & $\mathrm{N}$ & $\mathrm{P}$ & $\mathrm{K}$ & $\mathrm{N}$ & $\mathrm{P}$ & $\mathrm{K}$ \\
\hline Wheat & 3.8 & 0.2 & 19 & 3.7 & 0.2 & 18 & 2.3 & 0.2 & 13 & 2.7 & 0.2 & 12 & 20.7 & 2.6 & 5 & 18.2 & 3.3 & 5 & 19.8 & 3.1 & 4 & 18.8 & 3.1 & 5 \\
\hline Barley & 27.9 & 3.9 & 25 & 18.5 & 1.3 & 11 & 31.4 & 1.7 & 11 & 23.9 & 3.9 & 25 & a & $\mathrm{a}$ & $\mathrm{a}$ & $\mathrm{a}$ & a & $\mathrm{a}$ & $\mathrm{a}$ & $\mathrm{a}$ & a & $\mathrm{a}$ & $\mathrm{a}$ & a \\
\hline Sorghum & 8.9 & 1.6 & 9 & 8.8 & 2.6 & 12 & 9.5 & 1.6 & 18 & nd & nd & nd & 21.3 & 4.6 & 5 & 22.5 & 4.6 & 5 & 21.2 & 4.6 & 5 & nd & nd & nd \\
\hline Maize & 23.9 & 2.5 & 27 & 24.5 & 2.8 & 29 & 18.8 & 1.9 & 27 & 21.1 & 1.9 & 27 & $\mathrm{a}$ & $\mathrm{a}$ & $\mathrm{a}$ & a & a & a & $\mathrm{a}$ & $\mathrm{a}$ & $\mathrm{a}$ & $\mathrm{a}$ & $\mathrm{a}$ & $\mathrm{a}$ \\
\hline Oat & 27.8 & 3.2 & 25 & 21.4 & 2.8 & 29 & 19.6 & 2.8 & 30 & 20.0 & 3.0 & 30 & a & a & a & a & a & a & a & a & a & a & a & a \\
\hline Alfalfa & 27.0 & 1.8 & 9 & 27.8 & 1.8 & 8 & 34.2 & 2.0 & 17 & 25.8 & 2.0 & 17 & a & a & a & a & a & a & a & $\mathrm{a}$ & a & a & $\mathrm{a}$ & a \\
\hline Garlic & 17.6 & 1.8 & 26 & 12.1 & 1.2 & 36 & 17.6 & 2.4 & 22 & 10.7 & 2.6 & 20 & $18.0^{\mathrm{b}}$ & 1.0 & 5 & 16.0 & 1.4 & 6 & 17.0 & 1.5 & 6 & 14.0 & 1.6 & 4 \\
\hline Coriander & 27.5 & 3.6 & 42 & 28.6 & 3.8 & 36 & 38.8 & 3.6 & 28 & 36.7 & 3.6 & 24 & a & $\mathrm{a}$ & $\mathrm{a}$ & $\mathrm{a}$ & $\mathrm{a}$ & $\mathrm{a}$ & a & a & $\mathrm{a}$ & a & a & $\mathrm{a}$ \\
\hline
\end{tabular}

All data are in $\mathrm{g} \mathrm{kg}^{-1}$ dry matter.

${ }^{a}$ Only vegetative parts were harvested and except for coriander used as animal fodder.

b Dry bulbs. 

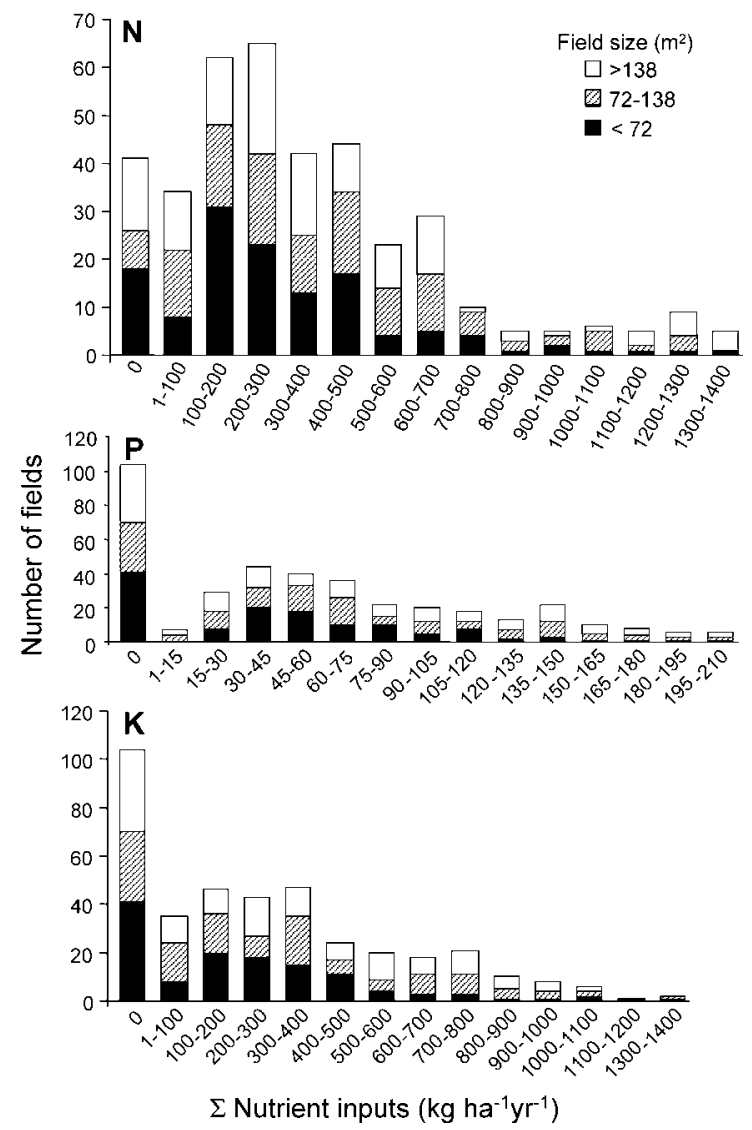

Fig. 5. Annual amounts of nitrogen (N), phosphorus $(\mathrm{P})$ and potassium $(\mathrm{K})$ applied as animal manure or synthetic fertilizers to the three different field size classes at the 'core oasis' of Balad Seet, Oman, from 2001 to 2002 . Columns show absolute frequencies in their respective input classes and comprise all 385 fields of the oasis system.

coefficients $(r)$ of 0.48 for fields and 0.47 for palm groves unrelated to their size (Fig. 7). However, on the smaller terrace systems palm groves tended to receive higher input intensities than wheat fields. The reverse was true on the largest systems, particularly for $\mathrm{N}$ and $\mathrm{P}$.

Partial nutrient balances were strongly positive regardless of terrace use in all systems, except for $\mathrm{K}$ in wheat fields at Al Lathli and Shbak (Fig. 8). For the 12-month measurement period nutrient gains were $47-222 \mathrm{~kg} \mathrm{~N} \mathrm{ha}^{-1}, 7-34 \mathrm{~kg} \mathrm{P} \mathrm{ha}^{-1}$ and 79-266 kg K $\mathrm{ha}^{-1}$ in palm groves and $63-157 \mathrm{~kg} \mathrm{~N} \mathrm{ha}^{-1}, 7-$ $19 \mathrm{~kg} \mathrm{Pha}^{-1}$, and -13 to $85 \mathrm{~kg} \mathrm{Kha}^{-1}$ in wheat

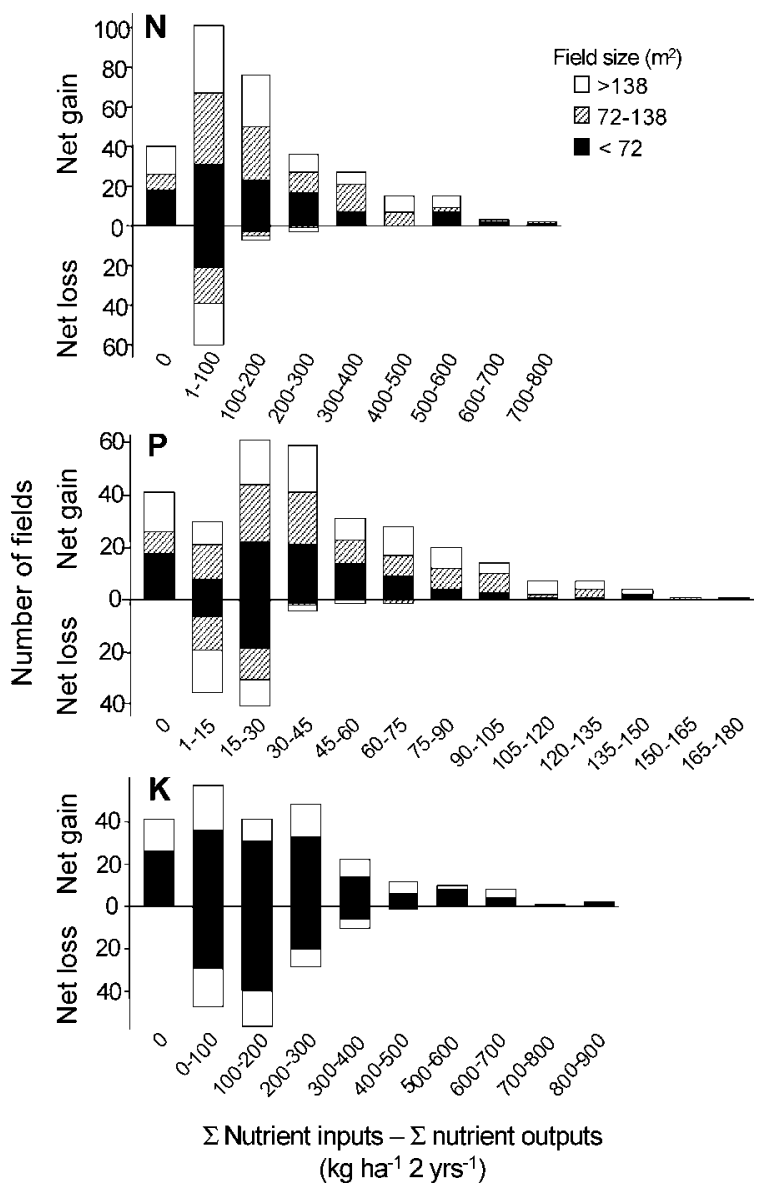

Fig. 6. Bi-annual partial balances (inputs minus outputs) of nitrogen $(\mathrm{N})$, phosphorus $(\mathrm{P})$ and potassium $(\mathrm{K})$ on the three different field size classes at the 'core oasis' of Balad Seet, Oman, from 2001 to 2002. Columns show absolute frequencies in their respective input classes and comprise all 385 fields of the oasis system.

fields (Fig. 8). Nutrient concentrations in the irrigation water were $0.49 \mathrm{mg} \mathrm{N}^{-1}, \quad 0.010 \mathrm{mg} \mathrm{Pl}^{-1}$, and $2.50 \mathrm{mg} \mathrm{K} \mathrm{l}^{-1}$.

\subsection{Annual partial nutrient balances at the oasis level}

Balad Seet. Input intensities far exceeded outputs for N, P and $\mathrm{K}$ on cropland but also on land planted to date palms. In cropland nutrient inputs from manure were 1.3-5.9-fold higher than those from synthetic fertilizers, in palm groves this ratio varied from 2.373 -fold. Nutrient gains per unit area in palm groves 


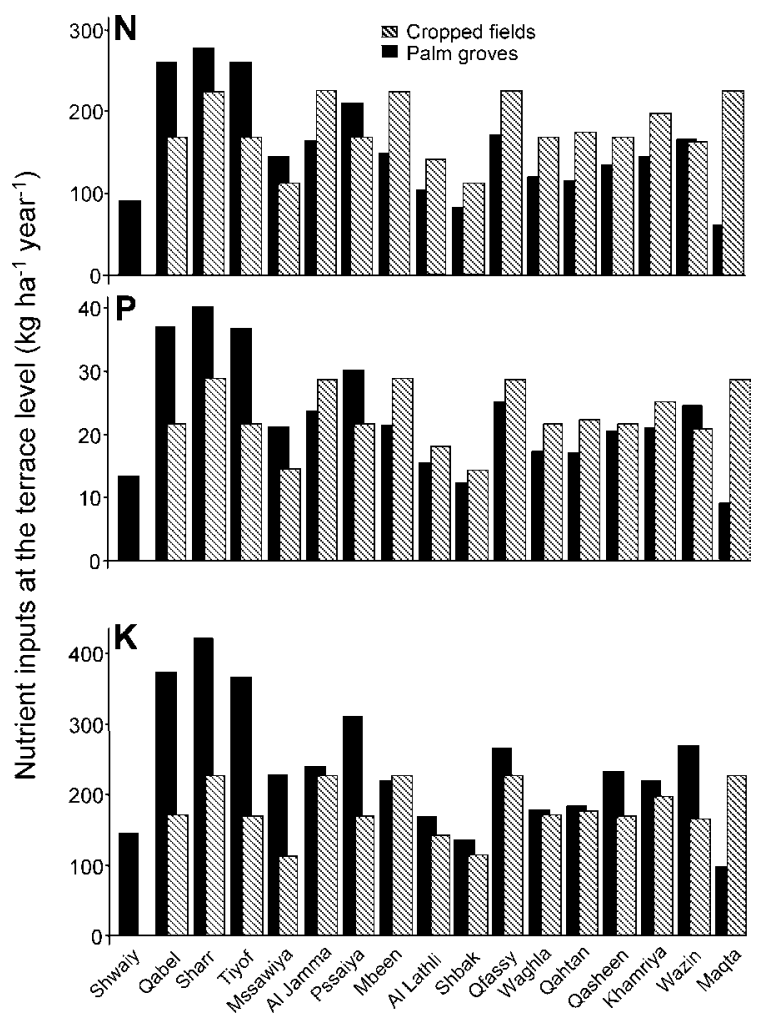

Fig. 7. Annual amounts of nitrogen $(\mathrm{N})$, phosphorus $(\mathrm{P})$ and potassium $(\mathrm{K})$ applied as animal manure to cropped fields and palm groves of the 17 terrace systems belonging to the 'scattered oasis' of Maqta, Oman, in 2001/2002. Note that the terrace systems on the $x$-axis are arranged in order from smallest (left) to largest (right).

were higher than on cropland, by $131 \%$ for $\mathrm{N}$, by $1 \%$ for $\mathrm{P}$, and by $106 \%$ for $\mathrm{K}$ (Table 4 ). The relatively lower rates of manure and synthetic fertilizers applied to palm groves compared to cropland were for $\mathrm{N}$ and $\mathrm{P}$ compensated by the application of human faeces. Compared to palm groves nutrient removal by harvested products from cropland was $344 \%$ higher for $\mathrm{N}, 231 \%$ higher for $\mathrm{P}$, and $131 \%$ higher for $\mathrm{K}$ (Table 4).

Overall nutrient surpluses on the cultivated oasis land were particularly high for $\mathrm{N}$ and $\mathrm{K}$. The application of human faeces amounted to $46 \%$ of the excess $\mathrm{N}, 65 \%$ of excess $\mathrm{P}$, and $24 \%$ of excess $\mathrm{K}$ (Table 4).

Maqta. An average of 16.0 and $9.3 \mathrm{t}_{\text {manure }} \mathrm{ha}^{-1}$ were applied to cropland and date palms, respectively.

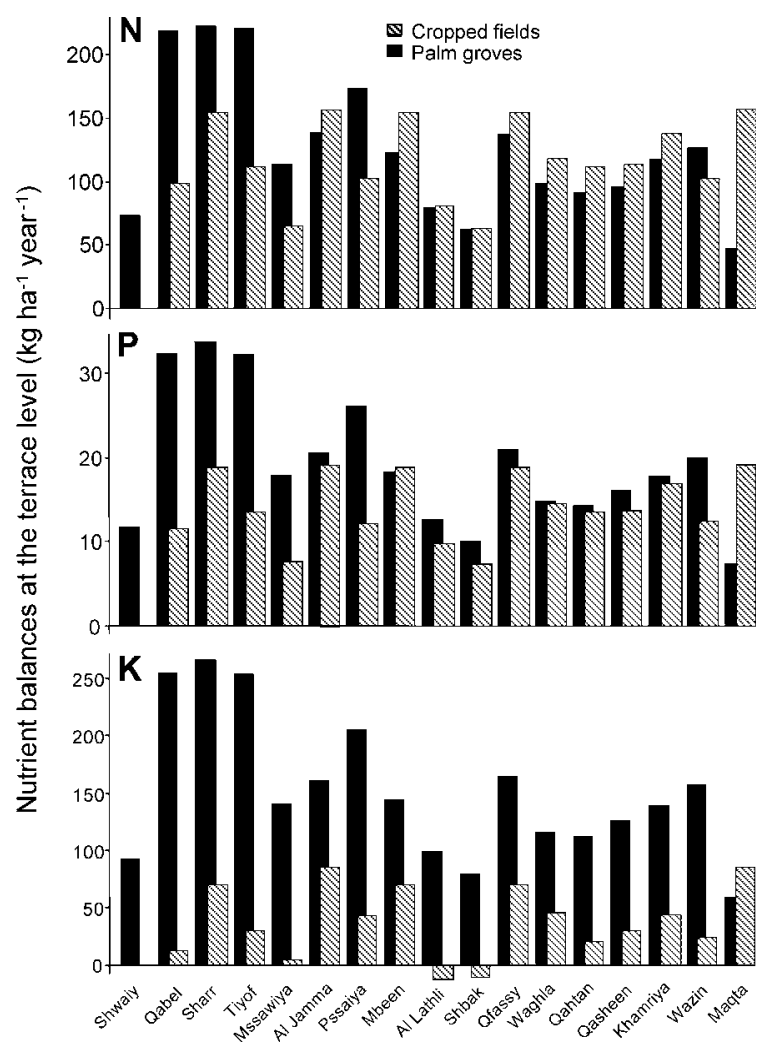

Fig. 8. Partial balances (inputs minus outputs) of nitrogen $(\mathrm{N})$, phosphorus $(\mathrm{P})$ and potassium $(\mathrm{K})$ on cropped fields and palm groves of the 17 terrace systems belonging to the 'scattered oasis' of Maqta, Oman, in 2001/2002. Note that the terrace systems on the $x$-axis are arranged in order from smallest (left) to largest (right).

Compared to cropland at Balad Seet, wheat fields at Maqta received on average only $61 \%$ of the total N, $39 \%$ of the P, and $64 \%$ of the K inputs. Similar differences in input intensities were noted for palm groves (Tables 4 and 5). In contrast to Balad Seet, irrigation and human faeces contributed only very small amounts of N, P, and K. Average annual areabased nutrient surpluses in cropland were similar at both oases, but were much higher for palm groves at Balad Seet than at Maqta (Tables 4 and 5).

\section{Discussion}

Yield levels were low for all of the irrigated crops except for sorghum, garlic, and alfalfa. This was likely 
Table 4

Annual inputs, outputs and partial balances of nitrogen $(\mathrm{N})$, phosphorus $(\mathrm{P})$ and potassium $(\mathrm{K})$ in cropland and palms groves at Balad Seet, Oman

\begin{tabular}{|c|c|c|c|c|c|c|c|}
\hline \multirow[t]{2}{*}{ Land use system } & \multirow[t]{2}{*}{ Source/process } & \multicolumn{3}{|c|}{ Input and output $\left(\mathrm{kg} \mathrm{ha}^{-1} \mathrm{yr}^{-1}\right)^{\mathrm{a}}$} & \multicolumn{3}{|c|}{ Partial balance $\left(\mathrm{kg} \mathrm{yr}^{-1}\right)^{\mathrm{a}}$} \\
\hline & & $\mathrm{N}$ & $\mathrm{P}$ & $\mathrm{K}$ & $\mathrm{N}$ & $\mathrm{P}$ & $\mathrm{K}$ \\
\hline \multirow[t]{6}{*}{ Cropland (4.6 ha) } & Synthetic fertilizer & 143 & 23.9 & 45 & 658 & 119.9 & 207 \\
\hline & Animal manure & 180 & 40.2 & 267 & 828 & 184.9 & 1228 \\
\hline & Irrigation water ${ }^{\mathrm{b}}$ & 10 & 5.2 & 17 & 46 & 23.9 & 78 \\
\hline & Symbiotic $\mathrm{N}_{2}$-fixation & 63 & n.a. ${ }^{\mathrm{c}}$ & n.a. & 290 & n.a. & n.a. \\
\hline & Crop harvest & -265 & -32.8 & -245 & -1219 & -150.9 & -1127 \\
\hline & Partial balance & 131 & 36.5 & 84 & 603 & 177.8 & 386 \\
\hline \multirow[t]{7}{*}{ Palm groves ( $8.8 \mathrm{ha})$} & Synthetic fertilizer & 59 & 1.8 & 4 & 519 & 15.8 & 35 \\
\hline & Animal manure + ashes & 141 & 8.0 & 289 & 1241 & 70.4 & 2543 \\
\hline & Irrigation water & 10 & 5.2 & 17 & 88 & 45.8 & 150 \\
\hline & Human faeces & 170 & 37.0 & 50 & 1496 & 325.6 & 440 \\
\hline & Date palm harvest (dates + stems + leaves) & -63 & -12.7 & -176 & -554 & -111.8 & -1549 \\
\hline & Harvested understory fodder & -14 & -1.5 & -11 & -123 & -15.8 & -97 \\
\hline & Partial balance & 303 & 37.8 & 173 & 2632 & 324.1 & 1469 \\
\hline Oasis (13.4 ha) & Total partial balance & 244 & 37.4 & 142 & 3235 & 501.9 & 1855 \\
\hline
\end{tabular}

All data are given as amounts per unit area and as totals (partial balance) for each land use system and represent annual averages of a 24-month measurement period from October 2000 to October 2002.

${ }^{a}$ Positive values indicate gains and negative ones losses.

b Total annual spring flow of $228,587 \mathrm{~m}^{3}$ was multiplied by nutrient concentrations of $0.57 \mathrm{mg} \mathrm{N}^{-1}, 0.30 \mathrm{mg} \mathrm{P}^{-1}$ and $1.0 \mathrm{mg} \mathrm{K} 1^{-1}$ and adjusted to the respective irrigated surface area. Average irrigation intensity was assumed to be similar on both types of land use.

c Not applicable.

due to the traditional germplasm with its low harvest index and to the low planting densities used. Total dry matter yields of alfalfa at Balad Seet were two to three times higher than those reported from other high intensity cultivation sites in the USA (Haby et al., 1999; Hoy et al., 2002) or in Brazil (Monteiro et al., 1998) even if yields per cutting reached similar levels (Ottman et al., 1996). They likely reflected the effects of monthly cuttings throughout the year and of rapid regrowth as reflected in the surprisingly high soil respiration rates detected in alfalfa plots (Wichern et al., 2004a). For all crops and both sites concentrations of $\mathrm{N}, \mathrm{P}$, and $\mathrm{K}$ in straw and grain (Table 2) were well above the critical levels reported by Bergmann (1988), thereby reflecting the high input intensity of manure and mineral fertilizers. Even if the preliminary Ndfa values used may be rather high, the results of the ${ }^{15} \mathrm{~N}$ experiment suggested a total annual $\mathrm{N}_{2}$ fixation in the above-ground TDM of as much as $480 \mathrm{~kg} \mathrm{ha}^{-1}$.

Partial balances of both oases were excessively high for all nutrients studied, thereby supporting our initial hypothesis that the two sites were large sinks for nutrients. Similar balance studies on rice in
Thailand indicated partial balances of only $+12 \mathrm{~kg} \mathrm{~N},+8 \mathrm{~kg} \mathrm{P}$ and $+7 \mathrm{~kg} \mathrm{~K} \mathrm{ha}^{-1}$ (Wijnhoud et al., 2003), whereas in Kenya total balances of $-71 \mathrm{~kg} \mathrm{~N},+3 \mathrm{~kg} \mathrm{P}$ and $-9 \mathrm{~kg} \mathrm{~K} \mathrm{ha}^{-1}$ were calculated for mixed crop-livestock farms (Van den Bosch et al., 1998b). At Balad Seet the large apparent nutrient excesses on cropland resulted mainly from annually applied animal manure and mineral fertilizers. In palm groves the application of human faeces played a major role in our calculated surpluses even if in reality some of the nutrients, particularly $\mathrm{N}$ may have been lost by volatilization or leaching prior to application (Table 4). Both types of organic inputs give evidence of the connection of today's oasis agriculture with the outside economy, which contributed large nutrient inputs through purchased food and fish meal as animal feed supplement. This was also reflected by the nutrient concentrations in manure. While $\mathrm{N}$ at $18 \mathrm{~g} \mathrm{~kg}^{-1}$ was similar to the $15-23 \mathrm{~g} \mathrm{~kg}^{-1}$ reported by Esse et al. (2001) and Brouwer and Powell (1998) for sheepcattle manure, $\mathrm{P}$ and $\mathrm{K}$, at 5 and $29 \mathrm{~g} \mathrm{~kg}^{-1}$, respectively, were much higher than respective values of 2 and $8 \mathrm{~g} \mathrm{~kg}^{-1}$ from the West African Sahel. 
Table 5

Annual inputs, outputs and partial balances of nitrogen $(\mathrm{N})$, phosphorus $(\mathrm{P})$ and potassium $(\mathrm{K})$ in cropland and palms groves at Maqta, Oman

\begin{tabular}{|c|c|c|c|c|c|c|c|}
\hline \multirow[t]{2}{*}{ Land use system } & \multirow[t]{2}{*}{ Source/process } & \multicolumn{3}{|c|}{ Input and output $\left(\mathrm{kg} \mathrm{ha}^{-1} \mathrm{yr}^{-1}\right)^{\mathrm{a}}$} & \multicolumn{3}{|c|}{ Partial balance $\left(\mathrm{kg} \mathrm{yr}^{-1}\right)^{\mathrm{a}}$} \\
\hline & & $\mathrm{N}$ & $\mathrm{P}$ & $\mathrm{K}$ & $\mathrm{N}$ & $\mathrm{P}$ & $\mathrm{K}$ \\
\hline \multirow[t]{6}{*}{ Cropland (0.4 ha) } & Synthetic fertilizer & n.a. ${ }^{b}$ & n.a. & n.a. & n.a. & n.a. & n.a. \\
\hline & Animal manure & 198 & 25.3 & 199 & 79 & 10.1 & 80 \\
\hline & Irrigation water $^{\mathrm{c}}$ & 2 & 0.05 & 12 & 0.9 & 0.02 & 5 \\
\hline & Symbiotic $\mathrm{N}_{2}$-fixation & n.a. & n.a. & n.a. & n.a. & n.a. & n.a. \\
\hline & Crop harvest & -64 & -9.0 & -145 & -26 & -3.6 & -58 \\
\hline & Partial balance & 136 & 16.4 & 66 & 54 & 6.5 & 27 \\
\hline \multirow[t]{7}{*}{ Palm groves $(3.6 \mathrm{ha})$} & Synthetic fertilizer & n.a. & n.a. & n.a. & n.a. & n.a. & n.a. \\
\hline & Animal manure + ashes & 104 & 15.4 & 166 & 374 & 55.4 & 598 \\
\hline & Irrigation water & 7 & 0.1 & 35 & 24 & 0.5 & 125 \\
\hline & Human faeces & 17 & 3.8 & 5 & 64 & 13.8 & 19 \\
\hline & Date palm harvest (dates + stems + leaves $)$ & -24 & -2.7 & -66 & -86 & -9.7 & -238 \\
\hline & Harvested understory fodder & -19 & -2.2 & -49 & -68 & -7.9 & -176 \\
\hline & Partial balance & 85 & 14.0 & 91 & 308 & 52.1 & 328 \\
\hline Oasis (4 ha) & Total partial balance & 90 & 14.2 & 89 & 283 & 47.5 & 298 \\
\hline
\end{tabular}

All data are given as amounts per unit area and as totals (partial balance) for each land use system and represent annual averages of a 12-month measurement period from February 2001 to March 2002.

${ }^{\text {a }}$ Positive values indicate gains and negative ones losses.

b Not applicable.

c Total annual spring flow of $51,666 \mathrm{~m}^{3}$ was multiplied by nutrient concentrations of $0.49 \mathrm{mg} \mathrm{N} 1^{-1}, 0.01 \mathrm{mg} \mathrm{P1^{-1 }}$ and $2.5 \mathrm{mg} \mathrm{K1^{-1 }}$ and adjusted to the respective irrigated surface area. Irrigation intensity was assumed to be similar on both types of land use for only 4 months during the remainder of the year cropland was left fallow and therefore not irrigated.

There was a clear differentiation of synthetic fertilizers and manure application for the different crops. Sorghum, alfalfa, and garlic received their nutrient inputs almost exclusively from animal manure, whereas wheat, barley, and coriander obtained large inputs from synthetic fertilizers (Table 6). The largest contribution to the positive partial oasis balances on cropland at Balad Seet came from sorghum and alfalfa, followed by garlic and coriander. In wheat and barley, however, inputs by far exceeded outputs for $\mathrm{N}$, whereas the reverse was true for $\mathrm{K}$ (Table 7).

The small size of the terraces in Maqta and their relatively large proportion of bare and abandoned fields is a typical feature of scattered oases in Oman (Siebert et al., 2005) which are subject to rapid decay under the current economic conditions. The positive partial nutrient balances based on large inputs of manure give, nevertheless, strong evidence of the continuing agro-pastoral linkage. The $47-72 \%$ smaller nutrient surpluses in palm groves compared to Balad Seet reflected the much lower population density in the Maqta territory, where the majority of its population is living in the small settlements surrounding the oasis in a $10 \mathrm{~km}$ radius. The much lower nutrient concentrations (except for K) in the irrigation water at Maqta reflect the absence of clothes washing places in the upper parts of the upper irrigation canal system, typical for Balad Seet.

The low $\mathrm{C} / \mathrm{N}$ ratios of $10-12$ in the upper $0.2 \mathrm{~m}$ layer of terrace soils at Balad Seet and Maqta (Wichern et al., 2004a,c) make it unlikely that substantial additional amounts of $\mathrm{N}$ surpluses can be stored for prolonged time periods in the soil bacterial biomass or in soil organic matter. Large gaseous and leaching losses of $\mathrm{N}$ are therefore likely to occur, particularly if manure and urea are not incorporated immediately after application or during likely leaching phases in winter months.

Soil $\mathrm{pH}$ values of 7.6-8.4 and day-time maximum temperatures between 30 and $45^{\circ} \mathrm{C}$ suggest that gaseous losses (particularly as a result of ammonia volatilization and to a likely minor proportion after denitrification) on the heavily manured soils undergoing repeated wetting and drying cycles may exceed the 11 and $14 \mathrm{~kg} \mathrm{~N} \mathrm{ha}^{-1}$ measured in irrigated maize-wheat systems on a sandy clay-loam 
Table 6

Summary statistics of sources (mineral versus organic) and intensity of nutrients (per harvest) applied to fields planted with wheat, barley, sorghum, alfalfa, garlic, and coriander at the oasis of Balad Seet, Oman, in 2001/2002

\begin{tabular}{|c|c|c|c|c|c|c|c|c|c|}
\hline & \multicolumn{3}{|l|}{ Wheat } & \multicolumn{3}{|l|}{ Barley } & \multicolumn{3}{|l|}{ Sorghum } \\
\hline & \multicolumn{3}{|c|}{ Type of fertilization (field no.) } & \multicolumn{3}{|c|}{ Type of fertilization (field no.) } & \multicolumn{3}{|c|}{ Type of fertilization (field no.) } \\
\hline & \multirow{3}{*}{$\begin{array}{l}\text { Mineral (30) } \\
\text { Intensity } \\
\left(\mathrm{kg} \mathrm{ha}^{-1}\right)\end{array}$} & \multirow{2}{*}{\multicolumn{2}{|c|}{$\begin{array}{l}\text { Organic (15) } \\
\text { Share of } \\
\text { manure }(\%)\end{array}$}} & \multirow{3}{*}{$\begin{array}{l}\text { Mineral (53) } \\
\text { Intensity } \\
\left(\mathrm{kg} \mathrm{ha}^{-1}\right)\end{array}$} & Organic (2) & Both (2) & \multirow{3}{*}{$\begin{array}{l}\text { Intensity } \\
\left(\mathrm{kg} \mathrm{ha}^{-1}\right)\end{array}$} & Organic (26) & Both (15) \\
\hline & & & & & \multicolumn{2}{|l|}{$\begin{array}{l}\text { Share of } \\
\text { manure }(\%)\end{array}$} & & \multicolumn{2}{|l|}{$\begin{array}{l}\text { Share of } \\
\text { manure }(\%)\end{array}$} \\
\hline & & Range & Mean & & Range & Mean & & Range & Mean \\
\hline $\mathrm{N}$ input & $50-375$ & $0-100$ & 37 & $34-352$ & $0-100$ & 8 & $0-423$ & $0-100$ & 85 \\
\hline $\mathrm{P}$ input & $0-102$ & $0-100$ & 73 & $0-50$ & $0-100$ & 24 & $0-94$ & $0-100$ & 98 \\
\hline \multirow[t]{6}{*}{$\mathrm{K}$ input } & $0-462$ & $0-100$ & 89 & $0-274$ & $0-100$ & 47 & $0-458$ & $0-100$ & 99 \\
\hline & \multicolumn{3}{|l|}{ Alfalfa } & \multicolumn{3}{|l|}{ Garlic } & \multicolumn{3}{|l|}{ Coriander } \\
\hline & \multicolumn{3}{|c|}{ Type of fertilization (field no.) } & \multicolumn{3}{|c|}{ Type of fertilization (field no.) } & \multicolumn{3}{|c|}{ Type of fertilization (field no.) } \\
\hline & \multirow{3}{*}{$\begin{array}{l}\text { Mineral (0) } \\
\text { Intensity } \\
\left(\mathrm{kg} \mathrm{ha}^{-1}\right)\end{array}$} & Organic (25) & Both (3) & \multirow{3}{*}{$\begin{array}{l}\text { Mineral }(0) \\
\text { Intensity } \\
\left(\mathrm{kg} \mathrm{ha}^{-1}\right)\end{array}$} & Organic (52) & Both (12) & \multirow{3}{*}{$\begin{array}{l}\text { Mineral (5) } \\
\text { Intensity } \\
\left(\mathrm{kg} \mathrm{ha}^{-1}\right)\end{array}$} & Organic (15) & Both (10) \\
\hline & & $\begin{array}{l}\text { Share of } \\
\text { manure }(\%)\end{array}$ & & & $\begin{array}{l}\text { Share of } \\
\text { manure }(\%)\end{array}$ & & & \multicolumn{2}{|l|}{$\begin{array}{l}\text { Share of } \\
\text { manure }(\%)\end{array}$} \\
\hline & & Range & Mean & & Range & Mean & & Range & Mean \\
\hline $\mathrm{N}$ input & $285-551^{\mathrm{a}}$ & $39-58$ & 52 & $177-514$ & $39-100$ & 96 & $31-503$ & $0-100$ & 69 \\
\hline $\mathrm{P}$ input & 34-100 & $70-100$ & 96 & $45-117$ & $66-100$ & 98 & 14-95 & $0-100$ & 84 \\
\hline $\mathrm{K}$ input & $190-467$ & $87-100$ & 99 & $250-558$ & $85-100$ & 99 & $25-527$ & $0-100$ & 94 \\
\hline
\end{tabular}

${ }^{a}$ About $45 \%$ of the total $\mathrm{N}$-input originated from symbiotic $\mathrm{N}_{2}$-fixation.

soil in Pakistan with 16 and $32 \mathrm{t}$ annually applied farmyard manure (Mahmood et al., 1997). On the Omani oasis terraces such gaseous losses are, however, tedious to measure representatively given the large variety of crops grown over time and distance. Experiments under controlled conditions, such as in field-based closed chambers and wind tunnels may be needed to derive and calibrate models for the agro-environmental conditions prevailing in both oases.

Table 7

Average crop-specific inputs, outputs and partial balances of nitrogen $(\mathrm{N})$, phosphorus $(\mathrm{P})$ and potassium $(\mathrm{K})$ for wheat, barley, sorghum, alfalfa, garlic, and coriander in cropping systems of Balad Seet, Oman, in 2001/2002

\begin{tabular}{|c|c|c|c|c|c|c|c|c|c|}
\hline & \multicolumn{3}{|c|}{ Wheat $\left(\mathrm{kg} \mathrm{ha}^{-1}\right)$} & \multicolumn{3}{|c|}{ Barley $^{\mathrm{a}}\left(\mathrm{kg} \mathrm{ha}^{-1}\right)$} & \multicolumn{3}{|c|}{ Sorghum $\left(\mathrm{kg} \mathrm{ha}^{-1}\right)$} \\
\hline & Inputs & Outputs & Partial balances & Inputs & Outputs & Partial balances & Inputs & Outputs & Partial balances \\
\hline $\mathrm{N}$ & 85 & 45 & 40 & 155 & 142 & 13 & 208 & 106 & 102 \\
\hline$P$ & 16 & 5 & 11 & 13 & 15 & -2 & 52 & 37 & 15 \\
\hline \multirow[t]{3}{*}{$\mathrm{K}$} & 72 & 82 & -10 & 37 & 111 & -74 & 276 & 125 & 151 \\
\hline & \multicolumn{3}{|c|}{ Alfalfa $\left(\mathrm{kg} \mathrm{ha}^{-1}\right)$} & \multicolumn{3}{|c|}{ Garlic $\left(\mathrm{kg} \mathrm{ha}^{-1}\right)$} & \multicolumn{3}{|c|}{ Coriander $\left(\mathrm{kg} \mathrm{ha}^{-1}\right)$} \\
\hline & Inputs & Outputs & Partial balances & Inputs & Outputs & Partial balances & Inputs & Outputs & Partial balances \\
\hline $\mathrm{N}$ & $322^{\mathrm{b}}$ & 198 & 124 & 121 & 75 & 46 & 179 & 111 & 68 \\
\hline $\mathrm{P}$ & 35 & 13 & 22 & 34 & 8 & 26 & 44 & 12 & 32 \\
\hline K & 184 & 104 & 80 & 185 & 54 & 131 & 203 & 110 & 93 \\
\hline
\end{tabular}

${ }^{\text {a }}$ Harvested as green animal fodder and fertilized mainly with urea.

b About $45 \%$ of the total $\mathrm{N}$-input originated from symbiotic $\mathrm{N}_{2}$-fixation. 
In irrigated maize under the cooler conditions of the North China Plain, $\mathrm{NH}_{3}$ losses of $44-48 \%$ of the applied $\mathrm{N}$ plus additional $\mathrm{N}_{2} \mathrm{O}$ emissions of about $2 \mathrm{~kg} \mathrm{~N} h a^{-1}$ during the 2 months following urea application at 75 and $200 \mathrm{~kg} \mathrm{ha}^{-1}$ were determined (Cai et al., 2002). In Indian rice-wheat systems on irrigation-supplemented alluvial soils recorded $\mathrm{NH}_{3}$ emissons were about $60 \mathrm{~kg} \mathrm{ha}^{-1}$ at $60 \mathrm{~kg}$ urea $\mathrm{N}$ plus $60 \mathrm{~kg} \mathrm{ha}^{-1}$ manure $\mathrm{N}$ for rice and $120 \mathrm{~kg} \mathrm{ha}^{-1}$ urea $\mathrm{N}$ for wheat (Banerjee et al., 2002).

Leaching losses of $\mathrm{N}$, but also of organic $\mathrm{P}$ might also be relatively large but limited to specific periods. Tracer experiments at Balad Seet monitoring the water movement (Luedeling et al., 2005) indicate that deep drainage may only occur during the winter months when abundance of water, lower evaporation, and occasional strong rainfall events cause a temporary and thorough wetting of the terrace soils.

Nutrient losses by erosion, in contrast, seem unlikely given the terrace structure that effectively prevents lateral soil movement. Similarly low should be atmospheric nutrient inputs given the large distance of the oases from sites of industrial emission or volcanic activity.

For our partial $\mathrm{N}$ balances nutrient concentrations in manure were based on measurements of fieldapplied manure compost. However, during storage of this material with its $\mathrm{C} / \mathrm{N}$ ratio varying from 24 to 16 for fresh and mature manure, respectively (Wichern et al., 2004b), considerable $\mathrm{NH}_{3}$-losses are likely which may far exceed the 5-24\% of total $\mathrm{N}$ measured by Petersen et al. (1998) for cattle and pig manure under temperate conditions.

\section{Conclusions}

The data provide solid evidence of the oases being large temporary sinks for nutrients until they are released to the surrounding atmosphere or watershed. Nutrient losses through leaching are probably restricted to the winter months when potential evaporation is much lower than in summer and when sufficient water is available to allow its regular application at $90 \mathrm{~mm}$ per irrigation event. It is this leaching, occasionally aggravated by a torrential rainfall which likely helps to avoid the built-up of toxic salt levels (Luedeling et al., 2005).
Ammonia volatilization, denitrification, and $\mathrm{NO}_{3}{ }^{-}$, $\mathrm{P}$ - and K-leaching losses in the highly spatially and temporarily diverse cropping patterns at Balad Seet will need further quantification to better explain the fate of the applied nutrients.

The apparent oversupply of $\mathrm{N}$ may be an already old, largely unavoidable phenomenon in these oases systems given volatilization losses due to high ambient temperatures and $\mathrm{pH}$ and leaching losses as a consequence of salt removal by drainage. The oversupply of $\mathrm{P}$ seems, in contrast, seems a relatively recent phenomenon reflecting the oases' overpopulation and the transformation of oasis agriculture from a need to survive to a mainly culturally based leisure.

\section{Acknowledgements}

The authors are grateful to two anonymous reviewers for their constructive comments on an earlier version of this paper and to E. Wiegard, C. Thieme, M. Ruckwied, and B. Heiligtag for their contributions to the plant and soil analyses. They are also indebted to Sultan Qaboos University, Muscat for technical and logistical assistance and to the Deutsche Forschungsgemeinschaft (DFG) for funding. We thankfully acknowledge the patience and hospitality of the oasis farmers at Balad Seet and Maqta.

\section{References}

Al-Maskri, M., Nagieb, M., Hammer, K., Filatenko, A.A., Khan, I., Buerkert, A., 2003. A note about Triticum in Oman. Genet. Resour. Crop Evol. 50 (1), 83-87.

Baijukya, F.P., de Steenhuijsen Piters, B., 1998. Nutrient balances and their consequences in the banana-based land use systems of Bukoba district, northwest Tanzania. Agric. Ecosyst. Environ. 71, 147-158.

Banerjee, B., Pathak, H., Aggarwal, P.K., 2002. Effects of dicyandiamide, farmyard manure and irrigation on crop yields and ammonia volatilization from an alluvial soil under a rice (Oryza sativa $\mathrm{L}$.)-wheat (Triticum aestivum $\mathrm{L}$.) cropping system. Biol. Fertility Soils 36 (3), 207-214.

Bergmann, W., 1988. Ernährungsstörungen bei Kulturpflanzen. Gustav Fischer Verlag, Stuttgart, 762 pp.

Brouwer, J., Powell, J.M., 1998. Increasing nutrient use efficiency in West-African agriculture: the impact of micro-topography on 
nutrient leaching from cattle and sheep manure. Agric. Ecosyst. Environ. 71, 229-239.

Buerkert, A., Mahler, F., Marschner, H., 1996. Soil productivity management and plant growth in the Sahel: potential of an aerial monitoring technique. Plant and Soil 180, 29-38.

Butterbach-Bahl, K., Stange, F., Papen, H., Li, C., 2001. Regional inventory of nitric oxide and nitrous oxide emissions for forest soils of Southeast Germany using the biogeochemical model PnET-N-DNDC. J. Geophys. Res. 106, 34155-34166.

Cai, G., Chen, D., White, R.E., Fan, X.H., Pacholski, A., Zhu, Z.L., Ding, H., 2002. Gaseous nitrogen losses from urea applied to maize on a calcareous fluvo-aquic soil in the North China Plain. Aust. J. Soil Res. 40 (5), 737-748.

De Jaeger, A., Nandwa, S.M., Okoth, P.F., 1998a. Monitoring nutrient flows and economic performance in African farming systems (NUTMON). I. Concepts and methodologies. Agric. Ecosyst. Environ. 71, 37-48.

De Jaeger, A., Kariuku, I., Matiri, F.M., Odendo, M., Wanyamana, J.M., 1998b. Monitoring nutrient flows and economic performance in African farming systems (NUTMON). IV. Linking nutrient partial balances and economic performance in three districts in Kenya. Agric. Ecosyst. Environ. 71, 215228.

Esse, P.C., Buerkert, A., Hiernaux, P., Assa, A., 2001. Decomposition of and nutrient release from ruminant manure on acid sandy soils in the Sahelian zone of Niger, West Africa. Agric. Ecosyst. Environ. 83, 55-63.

Gericke, S., Kurmies, B., 1952. Die kolorimetrische Phosphorsäurebestimmung mit Ammonium-Vandadat-Molybdat und ihre Anwendung in der Pflanzenanalyse. Z. Düngg. Pflanzenernähr. Bodenk. 59, 235-247.

Haby, V.A., Davis, J.V., Leonard, A.T., 1999. Response of overseeded alfalfa and bermudagrass to alfalfa row spacing and nitrogen rate. Agron. J. 91 (6), 902-910.

Harris, F.M.A., 1998. Farm-level assessment of the nutrient balance in northern Nigeria. Agric. Ecosyst. Environ. 71, 201-214.

Hoy, M.D., Moore, K.J., George, J.R., Brummer, E.C., 2002. Alfalfa yield and quality as influenced by establishment method. Agron. J. 94 (1), 65-71.

IFA, 2004. World Fertilizer Use Manual. International Fertilizer Industry Association (IFA), Paris, France http://www.fertilizer.org/ifa/publicat/html/pubman/manual.htm.

Ko, J.-Y., Kang, H.-W., 2000. The effects of cultural practices on methane emission from rice fields. Nutr. Cycl. Agroecosyst. 58, 311-314.

Luedeling, E., Nagieb, M., Wichern, F., Brandt, M., Deurer, M., Buerkert, A., 2005. Drainage, salt leaching and physicochemical properties of irrigated man-made terrace soils in a mountain oasis of northern Oman. Geoderma 125 (3-4), in press.

Mahmood, T., Tahir, G.R., Malik, K.A., Shamsi, S.R.A., 1997. Denitrification losses from an irrigated sandy-clay loam under a wheat-maize cropping system receiving different fertilizer treatments. Biol. Fert. Soils 26 (1), 35-42.

Monteiro, A.L.G., Costa, C., Silveira, A.C., 1998. Dry matter production and seasonal distribution and chemical composition of alfalfa cultivars (Medicago sativa L.). Revista Brasileira de Zootecnia (Braz. J. Anim. Sci.) 27 (5), 868-874.

Nagieb, M., 2004. Nährstoffflüsse und pflanzengenetische Ressourcen in zwei Bergoasen des nördlichen Omans. Ph.D. Thesis. University Kassel Press, Kassel, Germany 178 pp. ISBN 389958-098-2.

Nagieb, M., Häser J., Siebert S., Luedeling, E., Buerkert, A., 2004. Settlement history of a mountain oasis in northern Omanevidence from land use and archaeological studies. Die Erde 135 (1), 81-106.

Ottman, M.J., Tickes, B.R., Roth, R.L., 1996. Alfalfa yield and stand response to irrigation termination in an arid environment. Agron. J. 88 (1), 44-48.

Petersen, S.O., Lind, A.M., Sommer, S.G., 1998. Nitrogen and organic matter losses during storage of cattle and pig manure. J. Agric. Sci. 130, 69-79.

Schouw, N.L., Danteravanich, S., Mosbaeka, H., Tjella, J.C., 2002. Composition of human excreta-a case study from southern Thailand. Sci. Total Environ. 286, 155-166.

Siebert, S., Häser, J., Nagieb, M., Korn, L., Buerkert, A., 2005. Agricultural, architectural and archaeological evidence for the role and ecological adaptation of a scattered mountain oasis in Oman. J. Arid Environ 61 (3), in press.

Smaling, E.M.A., Stoorvogel, J.J., Windmeijer, P.N., 1993. Calculating soil nutrient balances in Africa at different scales. II. District scale. Fert. Res. 35, 237-350.

Smaling, E.M.A., Fresco, L.O., 1993. A decision-support model for monitoring nutrient balances under agricultural land use (NUTMON). Geoderma 60, 235-256.

Smaling, E.M.A., Fresco, L.O., de Jaeger, A., 1996. Classifying, monitoring and improving soil nutrient stocks and flows in African agriculture. Ambio 25, 492-496.

Stoorvogel, J.J., Smaling, E.M.A., 1994. Assessment of soil nutrient depletion in sub-Saharan Africa: 1983-2000, vol. 1. Main Report. The Winand Staring Centre, Wageningen, The Netherlands, $137 \mathrm{pp}$.

Van den Bosch, H., de Jaeger, A., Vlaming, J., 1998a. Monitoring nutrient flows and economic performance in African farming systems (NUTMON). II. Tool development. Agric. Ecosyst. Environ. 71, 49-62.

Van den Bosch, H., Gitari, J.N., Ogaro, V.N., Maobe, S., Vlaming, J., 1998b. Monitoring nutrient flows and economic performance in African farming systems (NUTMON). III. Monitoring nutrient flows and balances in three districts in Kenya. Agric. Ecosyst. Environ. 71, 63-80.

Wang, B., Adachi, K., 2000. Differences among rice cultivars in root exudation, methane oxidation, and populations of methanogenic and methanotrophic bacteria in relation to methane emission. Nutr. Cycling Agroecosyst. 58, 349-356.

Wassmann, R., Neue, H.U., Lantin, R.S., Makarim, K., Chareonsilp, N., Buendia, L.V., Rennenberg, H., 2000. Characterization of methane emissions from rice fields in Asia. II. Differences among irrigated, rainfed, and deepwater rice. Nutr. Cycl. Agroecosyst. 58, 13-22.

Wichern, F., Luedeling, E., Müller, T., Joergensen, R.G., Buerkert, A., 2004a. Field measurements of the $\mathrm{CO}_{2}$ evolution rate under 
different crops during an irrigation cycle in a mountain oasis of Oman. Appl. Soil Ecol. 25, 85-91.

Wichern, F., Müller, T., Joergensen, R.G., Buerkert, A., $2004 \mathrm{~b}$. Effects of manure quality and application forms on soil $\mathrm{C}$ and $\mathrm{N}$ turnover of a subtropical oasis soil under laboratory conditions. Biol. Fert. Soils 39 (3), 165-171.

Wichern, F., Lobe, I., Amelung, W., Müller, T., Joergensen, R.G., Buerkert, A., 2004c. Changes in amino acid enantiomers and microbial performance in soils from a subtropical mountain oasis in Oman abandoned for different periods. Biol. Fert. Soils 39 (6), 398-406.

Wijnhoud, J.D., Konboon, Y., Lefroy, R.D.B., 2003. Nutrient budgets: sustainability assessment of rainfed lowland rice-based systems in northeast Thailand. Agric. Ecosyst. Environ. 100, 119-127.

Xu, H., Cai, Z.C., Jia, Z.J., Tsuruta, H., 2000. Effect of land management in winter crop season on $\mathrm{CH}_{4}$ emission during the following flooded and rice-growing period. Nutr. Cycl. Agroecosyst. 58, 327-332. 